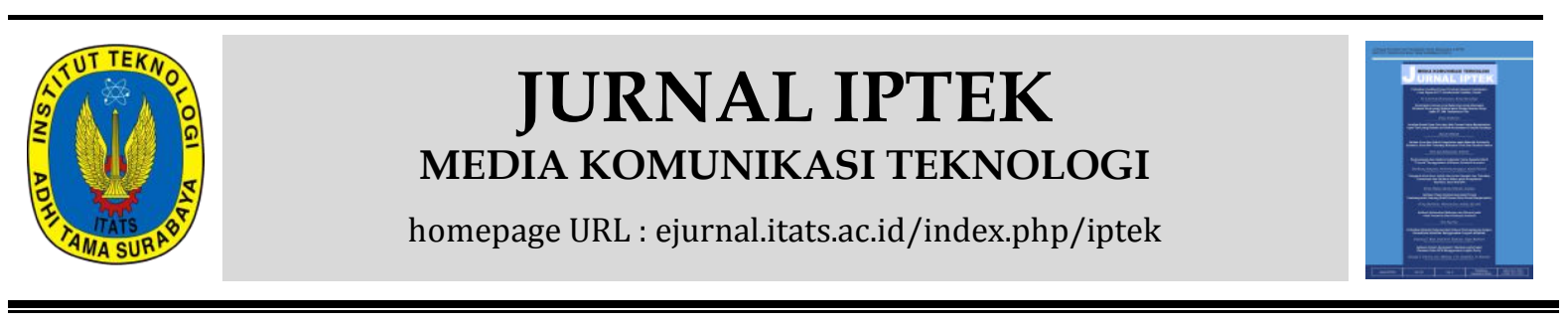

\title{
Pengaruh Ukuran Partikel Serbuk Bonggol Jagung Terhadap Sintesis Komposit Kampas Rem Non-Asbestos
}

\author{
Widya Emilia Primaningtyas ${ }^{1}$, Suheni ${ }^{2}$, Feri Alfian Pradana ${ }^{3}$ \\ 1,2,3 Jurusan Teknik Mesin, Fakultas Teknologi Industri \\ Institut Teknologi Adhi Tama Surabaya, Jl. Arief Rahman Hakim No.100 Surabaya, 60117
}

\begin{tabular}{l}
\hline INFORMASI ARTIKEL \\
\hline Jurnal IPTEK - Volume 22 \\
Nomer 1, Mei 2018 \\
ISSN:1411-7010 \\
e-ISSN:2477-507X \\
Halaman: \\
45-52 \\
DOI: \\
https://dx.doi.org/10.31284 \\
lj.iptek.2018.v22i1.235 \\
EMAIL \\
\hline
\end{tabular}

widyaemilia@itats.ac.id

\begin{abstract}
The development of vehicle production has occurred enormous nowadays, growth linear with the development of its spare parts. The use of asbestos-based materials in the manufacture of vehicle brake pad is considered to endanger health. Corn is one of the staple food of Indonesian people besides rice. Along with the needs of corn is high enough, then the production of waste generated from corn crops also increased. Corncob is one of the corn waste product that is potential to be utilized as a friction strengthening fiber in the composite of non-asbestos brake lining. This study aims to determine the effect of particle size of corncob powders, and structural mechanisms on non-asbestos brake composites. This study was conducted by varying the size of corncob powder (50, 80 and 100 mesh), also doing the process of carbonating on a portion of the powder. Subsequently each powder condition is mixed with resin and hardener with the composition ratio of the filler and reinforce as much as $20: 80 \% \mathrm{~V}$. Each specimen is tested for abrasive wear resistance test and photo macro test. The value collected from abrasive wear resistance test are high loss and weight loss. Obtained in the test, much smaller the particle size have better wear resistance. Rated the best wear resistance of the specimen consider by the value of weight loss produced by 100 mesh carbonated corncob powder as well with carbonated corncob powder worth $0.56 \pm 0.19 \mathrm{gr}$ while the best wear resistance of the specimen consider by the height loss is also generated by 100 mesh with an un-carbonated corncob powder worth $1.22 \pm 0.45 \mathrm{~mm}$. It was also concluded that the carbonate treatment for corncob powder had a relative effect on the increment of wear resistance value, considering by the high loss and weight loss value.
\end{abstract}

Keywords: Composite; Core of Corn Powder; Brake Pad; Non Asbestos.

\section{ABSTRAK}

Pengembangan produksi kendaraan bermotor yang berjalan pesat dewasa ini, berjalan seiring dengan pengembangan suku cadangnya. Pemakaian material berbasis asbes pada pembuatan kampas rem kendaraan dinilai membahayakan kesehatan. Jagung merupakan salah satu makanan pokok rakyat Indonesia selain nasi. Seiring dengan kebutuhan jagung yang cukup tinggi, maka produksi limbah yang dihasilkan dari tanaman jagung juga mengalami kenaikan. Bonggol jagung merupakan salah satu produk limbah jagung yang sangat potensial untuk dimanfaatkan sebagai serat penguat bahan friksi pada komposit kampas rem nonasbestos. Penelitian ini bertujuan untuk mengetahui pengaruh ukuran partikel serbuk bonggol jagung, dan mekanisme struktur pada komposit rem non asbestos. Penelitian ini dilakukan dengan memvariasikan berbagai ukuran serbuk bonggol jagung (50, 80 dan 100 mesh), juga melakukan proses pengarbonan pada sebagian dari serbuk. Setelahnya masing-masing kondisi serbuk dicampur dengan resin dan hardener dengan perbandingan komposisi material pengisi dan material penguat sebanyak 20:80\%V. Tiap-tiap spesimen di uji keausan abrasive dan foto makro. Hasil yang di dapatkan dari pengujian keausan abrasive adalah nilai kehilangan tinggi dan kehilangan berat. Didapatkan dalam pengujian, semakin kecil ukuran partikel maka ketahanan aus semakin baik. Nilai ketahanan aus terbaik dari 
spesimen kampas rem dinilai dari banyaknya kehilangan berat dihasilkan oleh variasi ukuran partikel 100 mesh baik dengan kondisi serbuk dikarbonkan maupun tidak dikarbonkan senilai 0,56 $\pm 0,19$ gr sedangkan nilai ketahanan aus terbaik dari spesimen kampas rem dinilai dari nilai kehilangan tinggi dihasilkan oleh variasi ukuran partikel 100 mesh dengan kondisi serbuk tidak dikarbonkan senilai 1,22 \pm $0,45 \mathrm{~mm}$. Disimpulkan pula perlakuan pengarbonan pada serbuk bonggol jagung relatif memberikan efek peningkatan nilai ketahanan aus, dinilai dari nilai kehilangan tinggi dan kehilangan beratnya.

Kata kunci: Komposit; Serbuk Bonggol Jagung; Kampas Rem; Non Asbestos.

\section{PENDAHULUAN}

Komposit didefinisikan sebagai suatu campuran dua komponen atau lebih, yang menghasilkan material baru yang memiliki sifat unggul dari material pembentuknya[1]. Material komposit dewasa ini digunakan di berbagai apliksi teknik, seperti konstruksi dari alat transportasi dan berbagai suku cadang otomotif. Secara sederhana sifat komposit dituliskan dengan sifat material penyusunnya dalam fraksi volume (sifat matriks $\mathrm{x}$ fraksi volume matriks + sifat penguat $\mathrm{x}$ fraksi volume penguat). Namun kenyataannya terdapat banyak faktor interaksi yang mempengaruhi hubungan antara matriks dengan penguat, atara lain geometri, ukuran, orientasi, dan distribusi penguat juga turut menentukan sifat mekanik suatu komposit[1].

Pertumbuhan teknologi yang semakin pesat berdampak langsung pertumbuhan bidang transportasi yang juga berbanding lurus dengan pengembangan suku cadang yang dibutuhkan. Kampas rem merupakan salah satu bagian dari sistem pengereman dari kendaraan yang bertujuan untuk mengatur kecepatan dengan mengkonversikan energi kinetik dari kendaraan ke energi panas yang dilepaskan ke lingkungan[2]. Permintaan kemampuan dari kampas rem pastilah dibutuhkan yang memiliki nilai koefisien gesek yang cukup tinggi dan stabil terhadap cakram rem dan tidak terdekomposisi atau rusak akibat gesekan dengan cakram rem terutama jika gesekan menghasilkan temperatur yang cukup tinggi[3]. Kampas rem yang umum digunakan pada kendaraan merupakan komposit campuran dari bahan yang berbasis asbes yang diikat oleh bahan pengikat berbahan polimer dan beberapa bahan yang lain[2]. Bahan berbasis asbes digunakan karena sifat tahan temperaturnya[4]. Akan tetapi pemakaian bahan asbestos telah dilarang penggunaannya akibat kandungan zat karsinogenik dan zat-zat yang berbahaya untuk lingkungan[5], sejak 1 Januari 1997 di Perancis[6]. Bahan yang berbasis asbes juga dapat membahayakan kesehatan pernafasan karena dapat melukai paru-paru jika terhirup[4].

Berbagai penelitian telah dikembangkan untuk melahirkan kampas rem yang berbahan bebas asbes. Berbagai macam limbah pertanian muncul sebagai alternative bahan baku yang ekonomis dalam pengembangan bantalan rem dengan tetap menjaga kelayakan komersial dan juga dapat mengendalikan pencemaran lingkungan. Menilik Indonesia yang merupakan negara agraris yang memiliki produksi sumber daya alam dalam bidang pertanian yang sangat besar, tentu saja menghasilkan limbah pertanian yang harus dikendalikan dengan upaya pemanfaatan tanpa menghasilkan permasalahan lingkungan baru. Ikpambese, K. K.,dkk (2016) mengembangkan kampas rem bebas asbes dari serat sabut kelapa, Idris, dkk (2015) membuat kampas rem bebas asbes berpenguat serbuk kulit pisang, dan Yawas, D. S., dkk (2016) menganalisa morfolgi dan sifat dari komposit kampas rem bebas asbes berbahan limbah cangkang kerang. Berdasarkan penjabaran latar belakang diatas, penelitian ini menggunakan bonggol jagung sebagai penguat kompositnya yang bertujuan mencari alternatif serat alam lain sebagai pengganti bahan asbestos dalam kampas rem. Penelitian ini bertujuan untuk mengetahui mekanisme struktur komposit kampas rem berpenguat serbuk bonggol jagung dengan variasi ukuran partikel, komposisi, dan perlakuan material pengisi. Sifat ketahanan aus dari model kampas rem diinvestigasi.

\section{TINJAUAN PUSTAKA}

Keausan didefinisikan sebagai kehilangan material secara progresif atau pemindahan sejumlah material dari suatu permukaan sebagai suatu hasil pergerakan relatif antara permukaan tersebut dan permukaan lainnya adalah akibat gesekan yang terjadi pada pembebanan dan gerakan. Keausan bukan merupakan sifat dasar material, melainkan respon material terhadap sistem luar 
(kontak permukaan). Keausan pada dasarnya memiliki berberapa mekanisme, yaitu Abrasi, Erosi, Adhesi, Fatik dan Korosi. Beberapa hal yang mempengaruhi keausan antara lain pembebanan, kecepatan, jenis dan jumlah pelumas, temperature, kekerasan permukaan, dan adanya pengotor[7]. Sebagaimana telah di jelaskan, material jenis apapun akan mengalami keausan dengan mekanisme yang beragam, pengujian keausan yang dilakukan juga beragam yang semuanya bertujuan untuk mensimulasikan kondisi keausan aktual. Pada penelitian ini uji keausan menggunakan jenis keausan abrasif.

Salah satu pengujian keausan abarasif dilakukan metode Ogoshi dimana benda uji memperoleh beban gesek dari piringan yang berputar (revolving disc). Pembebanan gesek ini akan menghasilkan kontak antar permukaan yang berulang-ulang yang pada akhirnya akan mengambil sebagian material pada permukaan benda uji. Besarnya jejak permukaan dari material tergesek itulahyang dijadikan dasar penentuan tingkat keausan pada material. Semakin besar dan dalam jejak keausan maka semakin tinggi volume material yang terlepas dari benda uji. Ilustrasi skematis dari kontak permukaan antara piringan putar dan benda uji disajikan pada Gambar 1.

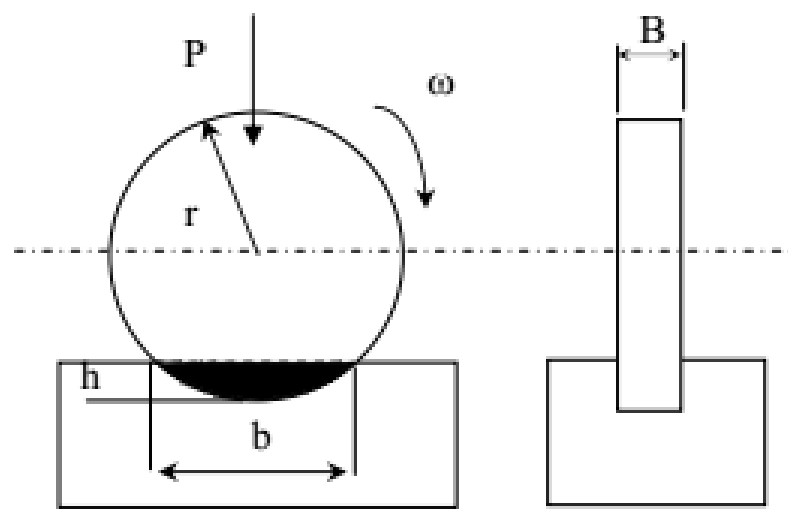

Gambar 1. Skematis dari kontak permukaan antara piringan putar dan benda uji pada uji keausan dengan metode ogoshi[8]

Perhitungan (rumus) yang digunakan pada pengujian abrasive ini sebagai berikut :

Untuk menentukan nilai kehilangan tinggi (Hight Loss) :

$$
\Delta \mathrm{h}=\mathrm{h}_{0}-\mathrm{h}_{1}
$$

Untuk menentukan nilai kehilangan berat (Weight Loss) :

$$
\Delta \mathrm{w}=\mathrm{w}_{0}-\mathrm{w}_{1}
$$

Untuk menentukan besarnya volume material yang terabrasi (W) :

$$
\mathrm{W}=\mathrm{B} \cdot \mathrm{b}^{3} / 12 \mathrm{r} \text {. }
$$

dimana,

B : tebal revolving disc $(\mathrm{mm})$

$\mathrm{r} \quad$ : jari-jari disc $(\mathrm{mm})$

b : lebar celah material yang terabrasi $(\mathrm{mm})$

Untuk menentukan Laju keausan (V) :

$\mathrm{V}=\mathrm{W} / \mathrm{x}=\mathrm{B} \cdot \mathrm{b}^{3} / 12 \mathrm{r} \cdot \mathrm{x}$

\section{METODE}

Pada penelitian ini material yang digunakan adalah bonggol jagung, aluminium foil, resin epoxy dan katalis, serta silicon rubber dan hardener-nya. Sedangkan alat yang dibutuhkan yaitu, tungku listrik, gunting, palu, blender, timbangan digital, ayakan 50, 80 dan 100 mesh, amplas grade 120 , mesin grinding dan polishing, penggaris, jangka sorong, dan vacuum cleaner. Pembuatan specimen kampas rem komposit berpenguat bonggol jagung dilakukan dalam beberapa tahap. Bonggol jagung yang masih basah dihilangkan kadar airnya dengan melakukan pengeringan dalam 2 tahap, pertama dikeringkan dengan bantuan cahaya matahari dan yang kedua dimasukkan dalam tungku bertemperatur $50^{\circ} \mathrm{C}$. Bonggol jagung yang sudah kering dikecilkan ukurannya dengan di palu ataupun digunting untuk mempermudah proses pembuatan serbuk. Potongan bonggol jagung 
yang berukuran lebih kecil dari sebelumnya dibagi menjadi dua untuk kemudian dilakukan variasi pengarbonan seperti yang ditunjukkan pada Gambar 2. Pengarbonan dilakukan dengan memasukkan potongan boggol jagung yang dibungkus alumunium foil[9] kedalam tungku $500^{\circ} \mathrm{C}$ selama 35 menit[10].

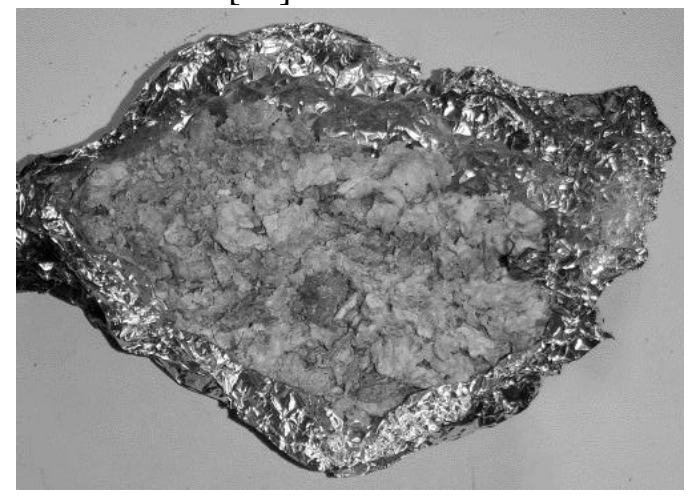

(a)

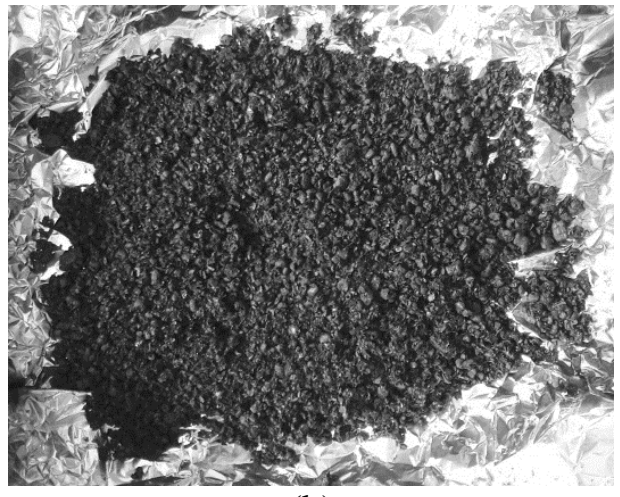

(b)

Gambar 2. (a) Potongan Bonggol Jagung sebelum dikarbonkan (b) Potongan Bonggol Jagung setelah dikarbonkan

Baik bonggol jagung yang dikarbonkan maupun yang tidak dikarbonkan diserbukkan dengan bantuan blender sampai ukuran 50, 80 dan 100 mesh seperti yang tersaji dalam Gambar 3 . Spesimen kampas rem dibuat dengan mencampurkan serbuk dengan resin epoxy dan katalisnya dengan komposisi serbuk dan resin sebanyak 20:80 \% V, kemudian diaduk merata dan dituang kecetakan yang terbuat dari rubber silicon berbentuk tabung dengan diameter $35 \mathrm{~mm}$ dengan tinggi 30mm seperti ditunjukkan Gambar 5 (a).

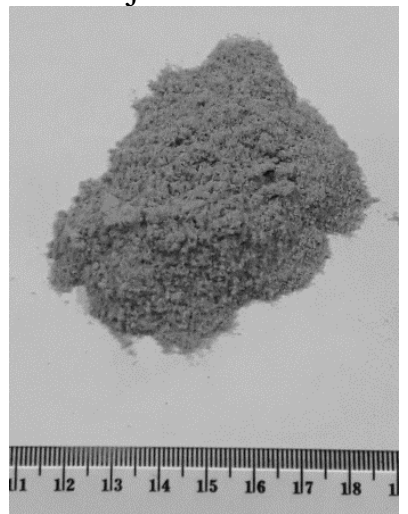

(a)

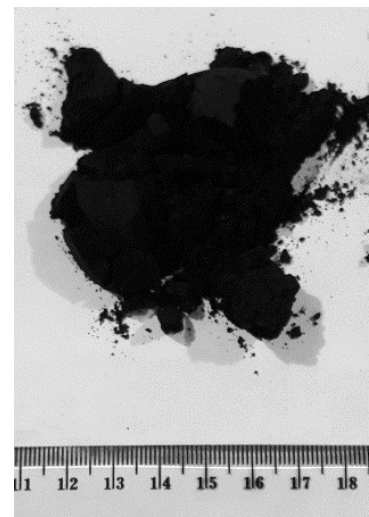

(b)

Gambar 3. (a) Serbuk Bonggol Jagung yang dikarbonkan (b) Serbuk Bonggol Jagung yang tanpa dikarbonkan

Setelah dituang dalam cetakan, sebelum mengeras, specimen di agitasi dan di vakum untuk meminimalisir adanya gelembung udara yang terperangkap dalam spesimen. Spesimen siap uji seperti yang ditunjukkan pada Gambar 5(b) diuji dengan uji keausan abrasif dengan metode ogoshi diatas kertas gosok grade 120 yang dipasang pada alat grinding dan polishing yang di modifikasi seperti ditunjukkan pada Gambar 4 dengan diberikan beban konstan dan tersebar merata sebesar 200 gr. Data yang didapat dari pengujian uji keausan abrasive adalah nilai kehilangan tinggu dan kehilangan berat yang dihitung dengan rumus pada Persamaan (1) atau (2) Tiap-tiap variasi ukuran partikel dan variasi perlakuan material pengisi dilakukan 3 kali pembuatan specimen dan pegujian. 


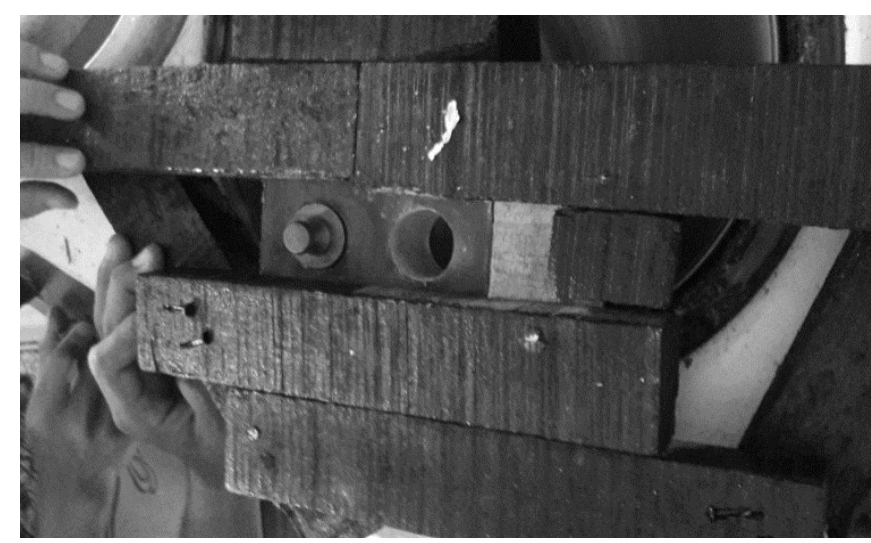

Gambar.4 . Modifikasi Mesin Grinding polishing dengan alat pemegang specimen uji keausan

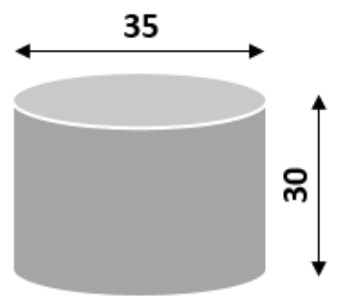

(a)

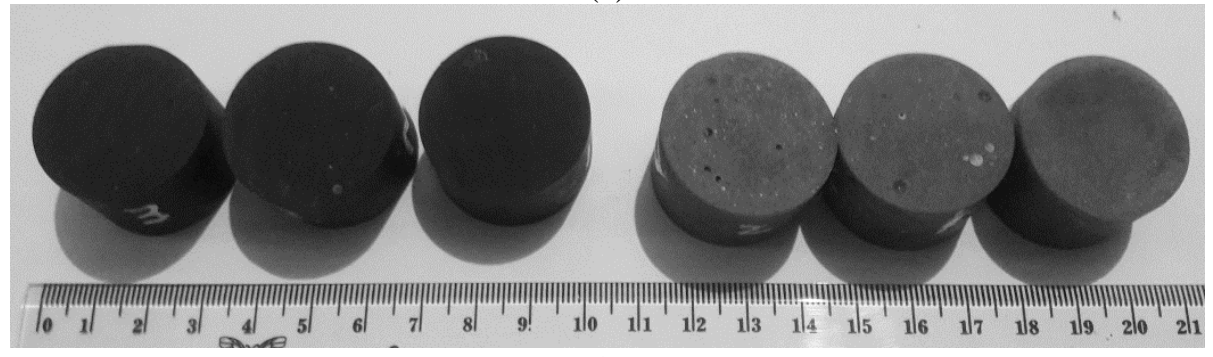

(b)

Gambar.5 . (a) Desain Spesimen Uji Keausan Abrasif (b) Spesimen Uji keausan abrasif siap uji

\section{HASIL DAN PEMBAHASAN}

\section{Pembahasan Data I}

Pengujian keausan dilakukan dengan cara melakukan pengukuran berat awal $\left(\mathrm{W}_{0}\right)$ dan tinggi awal $\left(\mathrm{H}_{0}\right)$ dari spesimen, setelah itu dilakukan pengukuran kembali berat akhir $\left(\mathrm{W}_{1}\right)$ dan tinggi akhir $\left(\mathrm{H}_{1}\right)$ setelah proses pengujian. Pada pengujian ini diberi beban tetap (konstan) sebesar 200 gram, dengan kecepatan konstan $300 \mathrm{rpm}$, waktu yang diberikan selama 10 menit dan amplas yang mempunyai grade 120 . Tabel 1 . adalah tabel yang menyajikan hasil kehilangan berat, dari perhitungan selisih berat awal $\left(\mathrm{W}_{0}\right)$ dan berat akhir $\left(\mathrm{W}_{1}\right)$ pada masing-masing specimen $(\Delta \mathrm{W})$. Tabel 2. adalah tabel yang menyajikan hasil kehilangan tinggi, dari perhitungan selisih tinggi awal $\left(\mathrm{H}_{0}\right)$ dan tinggi akhir $\left(\mathrm{H}_{1}\right)$ pada masing-masing specimen $(\Delta \mathrm{H})$. Sedangkan nilai $\overline{\Delta W}_{\text {dan }} \overline{\Delta H}$, merupakan hasil rata-rata kehilangan berat yang dilakukan dari pengujian 3 spesimen hasil repetisi, repetisi dilakukan agar mendapatkan suatu nilai kepercayaan dari data yang dihasilkan. 
Tabel 1. Tabel nilai kehilangan berat spesimen 50, 80 dan 100 mesh dengan kondisi serbuk dikarbonkan dan tanpa dikarbonkan

\begin{tabular}{|c|c|c|c|c|c|c|}
\hline $\begin{array}{l}\text { Perlakuan } \\
\text { (matrix } \\
\text { filler) }\end{array}$ & $\begin{array}{l}\text { Ukuran } \\
\text { Partikel } \\
\text { (mesh) }\end{array}$ & UJI KE & $\mathrm{W}_{0}($ gram$)$ & $\mathrm{W}_{1}$ (gram) & $\Delta \mathrm{W}($ gram $)$ & $\overline{\Delta W}$ \\
\hline \multirow{9}{*}{ 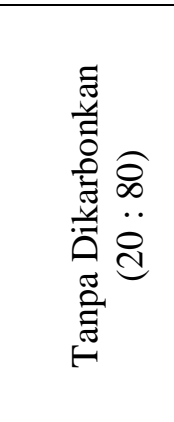 } & \multirow{3}{*}{50} & 1 & 15 & 14 & 1 & \multirow{3}{*}{$1,11 \pm 0,19$} \\
\hline & & 2 & 13,66 & 12,66 & 1 & \\
\hline & & 3 & 16,33 & 15 & 1,33 & \\
\hline & \multirow{3}{*}{80} & 1 & 14 & 13,33 & 0,67 & \multirow{3}{*}{$0,89 \pm 0,19$} \\
\hline & & 2 & 14 & 13 & 1 & \\
\hline & & 3 & 15 & 14 & 1 & \\
\hline & \multirow{3}{*}{100} & 1 & 13 & 12,66 & 0,34 & \multirow{3}{*}{$0,56 \pm 0,19$} \\
\hline & & 2 & 15,66 & 15 & 0,66 & \\
\hline & & 3 & 14 & 13,33 & 0,67 & \\
\hline \multirow{9}{*}{ 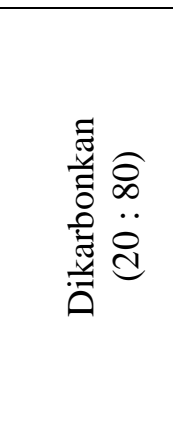 } & \multirow{3}{*}{50} & 1 & 15 & 13,66 & 1,34 & \multirow{3}{*}{$1,78 \pm 0,77$} \\
\hline & & 2 & 17 & 14,33 & 2,67 & \\
\hline & & 3 & 16 & 14,66 & 1,34 & \\
\hline & \multirow{3}{*}{80} & 1 & 15 & 14,33 & 0,67 & \multirow{3}{*}{$0,78 \pm 0,19$} \\
\hline & & 2 & 16,66 & 16 & 0,66 & \\
\hline & & 3 & 16 & 15 & 1 & \\
\hline & \multirow{3}{*}{100} & 1 & 15 & 14,66 & 0,34 & \multirow{3}{*}{$0,56 \pm 0,19$} \\
\hline & & 2 & 17 & 16,33 & 0,67 & \\
\hline & & 3 & 16,66 & 16 & 0,66 & \\
\hline
\end{tabular}

Tabel 2. Tabel nilai kehilangan tinggi spesimen 50, 80 dan 100 mesh dengan kondisi serbuk dikarbonkan dan tanpa dikarbonkan

\begin{tabular}{|c|c|c|c|c|c|c|}
\hline $\begin{array}{l}\text { Perlakuan } \\
\text { (matrix } \\
\text { filler) }\end{array}$ & $\begin{array}{l}\text { Ukuran } \\
\text { partikel } \\
\text { (mesh) }\end{array}$ & UJI KE & $\mathrm{H}_{0}(\mathrm{~mm})$ & $\mathrm{H}_{1}(\mathrm{~mm})$ & $\Delta \mathrm{H}(\mathrm{mm})$ & $\Delta \mathrm{H}($ rata2) \\
\hline \multirow{9}{*}{ 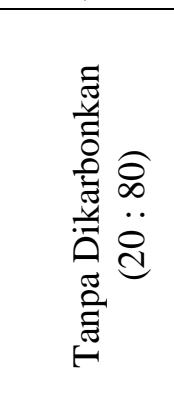 } & \multirow{3}{*}{50} & 1 & 21,2 & 19,1 & 2,1 & \multirow{3}{*}{$2,43 \pm 0,76$} \\
\hline & & 2 & 20,5 & 17,2 & 3,3 & \\
\hline & & 3 & 24,1 & 22,2 & 1,9 & \\
\hline & \multirow{3}{*}{80} & 1 & 19,1 & 17,5 & 1,6 & \multirow{3}{*}{$1,73 \pm 0,28$} \\
\hline & & 2 & 19,05 & 17 & 2,05 & \\
\hline & & 3 & 23 & 21,45 & 1,55 & \\
\hline & \multirow{3}{*}{100} & 1 & 18,45 & 17,7 & 0,75 & \multirow{3}{*}{$1,22 \pm 0,45$} \\
\hline & & 2 & 20,35 & 18,7 & 1,65 & \\
\hline & & 3 & 21,1 & 19,85 & 1,25 & \\
\hline \multirow{9}{*}{ 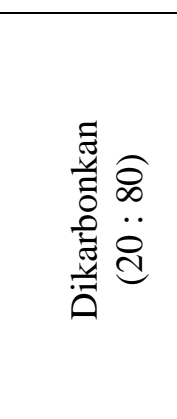 } & \multirow{3}{*}{50} & 1 & 20,1 & 18,1 & 2 & \multirow{3}{*}{$2,27 \pm 0,83$} \\
\hline & & 2 & 23,05 & 19,85 & 3,2 & \\
\hline & & 3 & 21,25 & 19,65 & 1,6 & \\
\hline & \multirow{3}{*}{80} & 1 & 18,25 & 16,75 & 1,5 & \multirow{3}{*}{$1,62 \pm 0,58$} \\
\hline & & 2 & 23,55 & 21,3 & 2,25 & \\
\hline & & 3 & 20 & 18,9 & 1,1 & \\
\hline & \multirow{3}{*}{100} & 1 & 19,8 & 19,1 & 0,7 & \multirow{3}{*}{$1,28 \pm 0,66$} \\
\hline & & 2 & 22,8 & 20,8 & 2 & \\
\hline & & 3 & 21,2 & 20,05 & 1,15 & \\
\hline
\end{tabular}




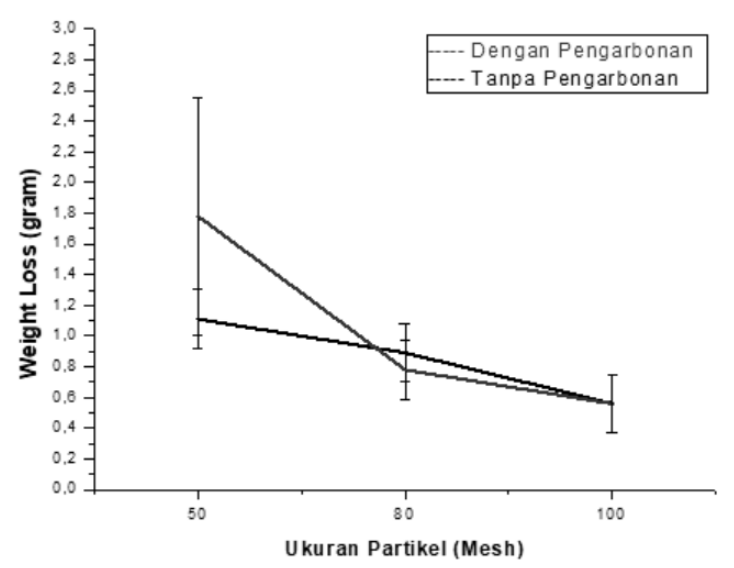

(a)

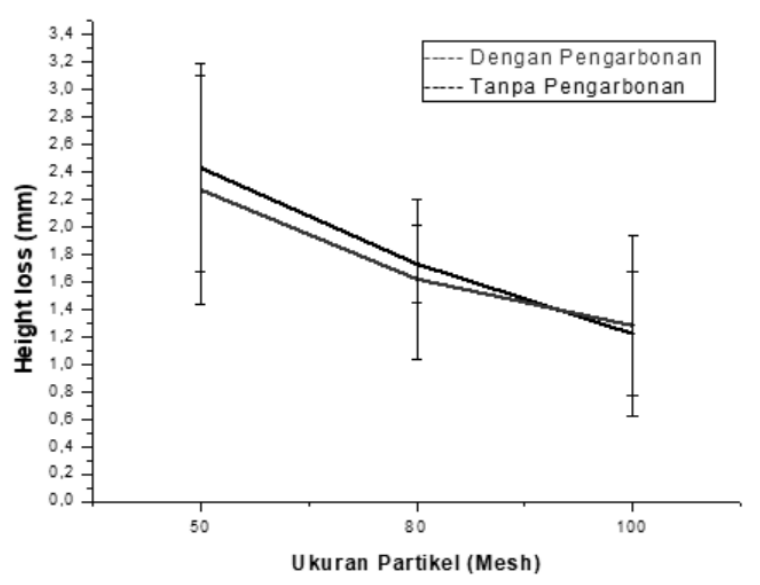

(b)

Grafik.1 (a) Nilai kehilangan berat (b) Nilai kehilangan tinggi untuk kondisi serbuk dikarbonkan dan tidak dikarbonkan

Grafik . 1 (a) merupakan grafik perbandingan nilai kehilangan berat dari komposit kampas rem non asbestos berpengisi serbuk bonggol jagung ukuran 50,80,100 mesh dengan kondisi serbuk dikarbonkan dan tidak dikarbonkan, sedangkan Grafik. 1 (b) merupakan perbandingan nilai kehilangan tingginya. Dapat dilihat dalam Grafik. 1 baik dalam nilai kehilangan berat maupun tinggi semakin kecil ukuran partikel didapatkan nilai tahan aus yang lebih baik dari yang dihasilkan oleh ukuran partikel yang lain. Hal ini dihasilkan karena ukuran partikel yang semakin kecil memiliki nilai packing factor yang semakin tinggi atau diartikan sebagai kemampuan suatu partikel material untuk menumpuk satu dengan yang lainnya yang semakin baik. Dengan kemampuan menumpuk satu dan lainnya yang semakin baik maka membuat komposit yang dihasilkan semakin padat dan memiliki ikatan mekanik antar partikel semakin baik sehingga menghasilkan nilai tahan abrasi yang semakin baik. Pada perlakuan pengarbonan pada bahan penguat, yang pada hipotesa ditujukan untuk meningkatkan kandungan karbon dalam serat alam yang diharapkan untuk menaikkan sifat mekanik dari komposit yang dibentuk, menunjukkan peningkatan yang relative terhadap nilai ketahanan aus jika dibandingkan dengan hasil ketahanan aus yang dihasilkan oleh bahan penguat yang tidak dikarbonkan. Maka upaya peningkatan nilai tahan aus dapat dilakukan dengan mengkarbonkan bahan penguat penyusun komposit.

Pada pengujian foto makro yang nampak pada Gambar 6. (a) nampak spesimen komposit kampas rem non asbestos berpengisi serbuk bonggol jagung setelah proses agitasi, sedangkan pada Gambar 6 (b) adalah specimen setelah melalui proses agitasi dan vakum. Spesimen yang warnanya lebih gelap merupakan spesimen komposit kampas rem non asbestos berpengisi serbuk bonggol jagung dengan pengarbonan.

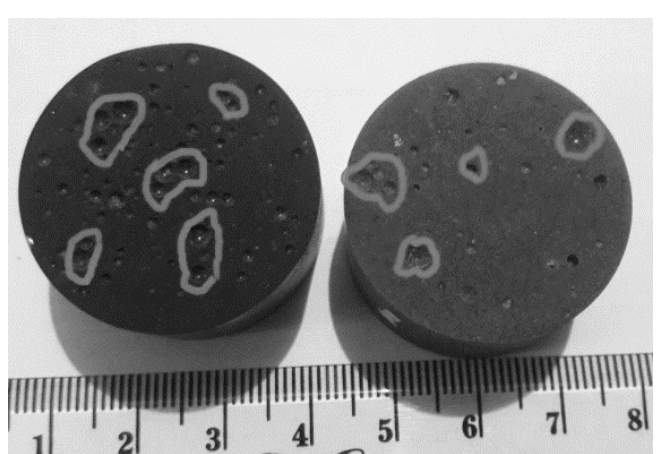

(a)

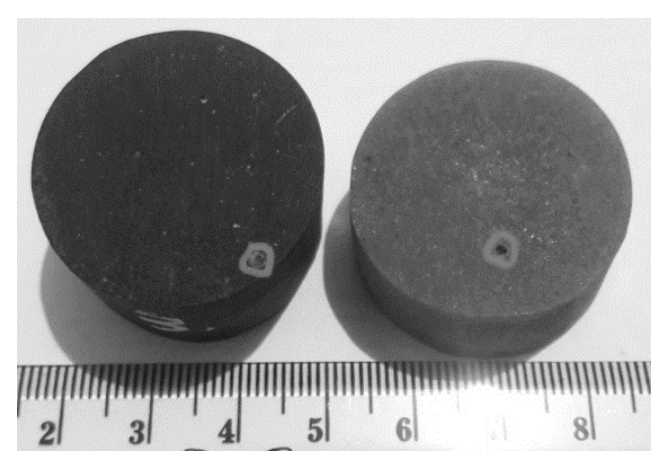

(b)

Gambar.6 Spesimen setelah melewati proses (a) agitasi (b) agitasi dan vakum.

Gambar 6 (a) dan (b) dapat diketahui bahwa proses agitasi dan vakum dalam proses fabrikasi spesimen komposit kampas rem non asbestos berpengisi serbuk bonggol jagung lebih 
optimal untuk mengurangi masuknya gelembung udara yang mungkin terjebak dalam proses pencetakan akibat proses pengadukan dan penuangan.

\section{KESIMPULAN}

Semakin kecil ukuran partikel serbuk bonggol jagung yang digunakan dalam pembuatan komposit kampas rem non asbestos dari serbuk bonggol jagung, memberikan nilai pengurangan berat dan tinggi yang minimum pada pengujian keausan abrasif, yang dapat diartikan memiliki nilai tahan aus yang tertinggi. Nilai ketahanan aus terbaik dari spesimen kampas rem dinilai dari banyaknya kehilangan berat dihasilkan oleh variasi ukuran partikel 100 mesh baik dengan kondisi serbuk dikarbonkan maupun tidak dikarbonkan senilai $0,56 \pm 0,19$ gr sedangkan nilai ketahanan aus terbaik dari spesimen kampas rem dinilai dari nilai kehilangan tinggi dihasilkan oleh variasi ukuran partikel 100 mesh dengan kondisi serbuk tidak dikarbonkan senilai 1,22 $\pm 0,45 \mathrm{~mm}$. Proses pengarbonan serbuk bonggol jagung yang bertindak sebagai material pengisi relatif meningkatkan nilai tahan aus pada komposit kampas rem. Didapatkan nilai yang berbeda signifikan $(\mathrm{P}<0.05)$ antara nilai ketahanan aus dari susunan komposit kampas rem non asbestos dari serbuk bonggol jagung dari susunan komposit yang berasal dari variasi ukuran partikel, maupun variasi perlakuan pada material pengisi. seragam dengan sudut susunan serat kaca yang divariasikan.

\section{DAFTAR PUSTAKA}

[1] Sulistijono. 2012 .Mekanika Material Komposit. Surabaya : Institut Teknologi Sepuluh November.

[2] Idris, U.D., Aigbodion, V.S., Abubakar, I.J., Nwoye, C.I., 2015. Eco-friendly asbestos free brake-pad: using banana peels. J. King Saud Univ.-Eng. Sci. 27 (2), 185-192.

[3] Efendy, H., Wan Mochamad, W-M., Yusuf, N.B.M., 2010. Develop-ment of natural fiber in Non-metallic brake friction material. Seminar Nasional Tahunan Teknik Mesin (SNTTM), 1315, Ke-9 Palembang.

[4] Yawas, D. S., Aku, S. Y., \& Amaren, S. G. 2016. Morphology and properties of periwinkle shell asbestos-free brake pad. Journal of King Saud University Engineering Sciences, 28(1), $103-109$.

[5] Ikpambese, K. K., Gundu, D. T., \& Tuleun, L. T. 2016. Evaluation of palm kernel fibers (PKFs) for production of asbestos-free automotive brake pads. Journal of King Saud University Engineering Sciences, 28(1), 110-118.

[6] Lagel, M. C., Hai, L., Pizzi, A., Basso, M. C., Delmotte, L., Abdalla, S., ... Al-Marzouki, F. M. 2016. Automotive brake pads made with a bioresin matrix. Industrial Crops and Products, 85, 372-381.

[7] Pratama. 2013. "Analisa Sifat Mekanik Komposit Bahan Kampas Rem Dengan Penguat Fly Ash Batubara ".Makassar : Universitas Hasanuddin.

[8] Yuwono, A.H. 2009. Praktikum Karakterisasi Material 1, Pengujian Merusak (Destructive Testing). Jakarta : Universitas Indonesia.

[9] Andi Cahyanto. 2012. "Sifat Mekanis dan Sifat Fisis Komposit Berpenguat Serat Kulit Jagung dan Serbuk Gergaji Kayu Jati dengan Perbandingan Fraksi Berat 30\%:70\%,50\%:50\%,70\%:30\% Berskin Aluminium Foil untuk Penggunaan Pelapis Dalam Atap" Universitas Muhammadiyah Surakarta.

[10] Fuad Dwi Fitrianto, Yuyun Estriyanto, dan Budi Harjanto. 2012. "Pemanfaatan Serbuk Tongkol Jagung Sebagai Alternatif Bahan Friksi Kampas Rem Non-Asbestos Sepeda Motor". Universitas Surakarta. 